\title{
Genetic Polymorphisms of the CX3CR1 Gene Associated with HIV-1 Infections in Kenyan Population
}

Lamech M Mwapagha'-3, Zipporah W Ng'ang'a², Shem P Mutuiri'-4, Barbara B Miheso ${ }^{2}$ and Samoel A Khamadi ${ }^{3}$

${ }^{1}$ Department of Natural and Applied Sciences, Faculty of Health and Applied Sciences, Namibia University of Science and Technology, 13 Storch Street Windhoek, Namibia

${ }^{2}$ Institute of Tropical Medicine and Infectious Diseases, Jomo Kenyatta University of Agriculture and Technology, Kenya

${ }^{3}$ Center for Virus Research, Kenya Medical Research Institute, Kenya

${ }^{4}$ Kenyatta University School of Pure and Applied Sciences, Department of Microbiology, Kenya

\begin{abstract}
Introduction: Repeated exposure to Human Immunodeficiency Virus (HIV) does not always result in infection. Understanding the mechanisms that confer protection against progressive infection with HIV-1 may be useful in the development of appropriate interventions. The impact of $C X 3 C R 1$ polymorphisms on human immunodeficiency virus type 1 (HIV-1) pathogenesis is controversial, with conflicting reports of their role in disease progression in HIV-1 infected individuals. The aim of this study is to characterize polymorphisms of the CX3CR1 co-receptor gene among HIV infected adults and infants in a Kenyan Population.
\end{abstract}

Methods: Clinical samples were obtained from $200 \mathrm{HIV}$ infected infants and $200 \mathrm{HIV}$ infected adults and genotyped for the CX3CR1 gene 280M and 249I mutations. These were identified by PCR-RFLP analysis after amplification of a 588 base pair sequence of CX3CR1 gene.

Results: In determining the presence of T280M and V249I haplotypes it was found that overall, infants had higher percentages of the wild type alleles at $(42 \%$ and $45 \%)$, respectively compared to adults $(37 \%$ and $36 \%)$ respectively. In the case of heterozygous mutants, adults had higher percentages $(11 \%$ and $12 \%)$, respectively than among infants $(7 \%$ and $4 \%)$, respectively. Adults also had higher percentages of homozygous mutants of $(2 \%)$ compared to infants $(1 \%)$. This study showed that the differences in mutations of CX3CR1 gene allele in I249 and M280 was $p=0.075$ and $p=0.215$, respectively which was not statistically significant $(p>0.05)$.

Conclusion: This study showed that CX3CR1 gene polymorphisms exist in Kenya though the numbers of mutations are at very low levels to warrant any meaningful impact in the population in terms of HIV-1 disease progression. It is probable that alternative mechanisms are operating in conferring resistance to HIV-I infection. Further in vitro cellular studies need to be carried out to determine the exact role of CX3CR1 gene mutations in HIVIAIDS pathogenesis.

Keywords: HIV-1; Fractalkine; Chemokine; Pathogenesis; Mutations

\section{Introduction}

Human Immunodeficiency Virus (HIV) uses gp120 and gp41 proteins on its surface to attach to the CD4 molecule on cells. In addition to the CD4 receptor, HIV must also bind to co-receptors on the cell surface that aid in viral attachment and entry into host cells. The most common co-receptors are CCR5 and CXCR4 [1,2]. Polymorphisms in genes encoding a number of chemokines have been implicated in differential outcomes of HIV infection and disease progression. These chemokines include regulated on activation normal T-cell expressed and secreted (RANTES), stromal cell-derived factor 1 (SDF1), and chemokine receptors such as C-X3-C chemokine receptor 1 (CX3CR1) and $\mathrm{C}-\mathrm{C}$ motif chemokine receptor 2 (CCR2) [3-7]. There has been intense interest in why some people with HIV progress slowly to disease and have longer survival. The proportion of people who will progress slowly to AIDS, or not progress at all, has not been established. It was shown in a recent French study that $9 \%$ of HIV-infected patients can control HIV viral loads for up to five years in the absence of antiretroviral therapy [8]. There are competing views regarding long-term survival. There is some evidence that a distinct group of long-term survivors does not exist. Rather, so-called 'longterm non-progressors' are the slowest progressors across a continuous spectrum. Several studies have suggested that when a group of longterm progressors is observed over time, a growing proportion start to exhibit signs of disease progression [9]. There is evidence though that some people do not progress at all. These patients seem able to control HIV infection, possibly due to the activity of CD8 cytotoxic
T-cells or due to the genetic make-up of the body's immune system. Reports suggest that non-progression has not been due to viral defects [10]. In some cases deletion in parts of HIVs genome has been found to be responsible for long-term non-progression. This has occurred in isolated groups of individuals infected with unusual strains of HIV that have parts of their nef gene missing [11].

Polymorphism of the CX3CR1 gene may be associated with the prognosis of HIV infection the function of FKN among HIVinfected patients is unknown, except in the brain. The mechanism by which the FKN/CX3CR1 complex may influence the course of HIV infection is thus unknown. Increased CX3CR1 expression and activity in both naïve and memory Th lymphocytes correlates with the rate of replication of HIV. This dysregulation is observed even in patients with treatment failure, i.e., those with uncontrolled viral replication despite antiviral drugs [12].

*Corresponding author: Samoel Ashimosi Khamadi, Kenya Medical Research Institute (KEMRI), PO Box 54840-00200 Nairobi, Kenya; Tel: +254722807841; E-mail: skhamadi@gmail.com

Received July 10, 2017; Accepted July 17, 2017; Published July 24, 2017

Citation: Mwapagha LM, Ng'ang'a ZW, Mutuiri SP, Miheso BB, Khamadi SA (2017) Genetic Polymorphisms of the CX3CR1 Gene Associated with HIV-1 Infections in Kenyan Population. J AIDS Clin Res 8: 712. doi: 10.4172/2155-6113.1000712

Copyright: ( 2017 Mwapagha LM, et al. This is an open-access article distributed under the terms of the Creative Commons Attribution License, which permits unrestricted use, distribution, and reproduction in any medium, provided the original author and source are credited. 
Control of HIV replication following initiation of ARV treatment rapidly normalizes the function of CX3CR1 in Th lymphocytes. This may stop FKN-mediated accumulation of Th lymphocytes in tissues and this may account for the rapid rise of the circulating memory Th lymphocyte count in treated patients, which has been shown to reflect redistribution of these cells from tissues to blood [13].The ability of particular alleles of the CX3CR1 gene to affect the course of HIV infection shows that the FKN/CX3CR1 complex influences the pathophysiology of HIV infection. CX3CR1 gene is less expressed in bronchial biopsies of asthmatic subjects and is hypothesized as a candidate gene in asthma pathogenesis $[14,15]$. Two non-synonymous single- nucleotide polymorphisms affecting codons 249 and 280 of CX3CR1 have been identified that are in complete linkage disequilibrium and that were both associated with reduced prevalence of atherosclerosis and coronary endothelial dysfunction in an NIH cardiac catheterization. CX3CR1-M280, a mutant form of the chemokine receptor CX3CR1, is defective in adhesive and chemotactic activity in vitro and is associated with lower risk of CVD [16]. Since the CX3CR1-M280 but not the CX3CR1-I249 allele is consistently associated with reduced risk of CVD, it is speculated that CX3CR1-M280 is the most likely cause of the functional defect. In addition, CX3CR1-M280 may be a useful genetic probe to evaluate the potential role of CX3CR1 in the pathogenesis of other inflammatory diseases in humans.

Genetic variants that alter the expression of functional CX3CR1 can profoundly influence the risk and rate of HIV-1-related disease in infants. Infants with the wild-type CX3CR1 V/V249 genotype, which has been associated with greater binding to fractalkine, compared with that in individuals with the I/I249 genotype experienced slower HIV-1 disease progression than did infants with the I/I249 genotype; however, the disease progression in V/I249 heterozygotes was similar to that in infants with the V/V249 genotype. Similarly, the T280 allelic variant, also associated with enhanced binding of fractalkine, was associated with slower disease progression, compared with the M280 allele [17].

The impact of polymorphisms in CX3CR1 on disease progression in HIV-1 infected adults remains controversial. In at least two HIV1-infected cohorts, no association was observed between the CX3CR1 M280 allele and disease progression; In a third study, similar frequencies of CX3CR1 249 and 280 genotypes were observed in patients with rapid progression and those without progression [18]. This study aims to characterize polymorphisms of the CX3CR1 co-receptor gene that have been found to influence HIV-1 disease progression.

\section{Materials and Methods}

\section{Study participants}

After ethical approval and informed consent, 200 clinical samples were used in the study. These comprised of samples from $100 \mathrm{HIV}$ infected adults and 100 HIV infected infants obtained during period between August and December 2007, who were drug naïve and at WHO first stage of the disease. The sample size was determined on a simple random sampling technique using an expected genotype frequency of $14 \%$ [19]. All samples were collected after obtaining approval from KEMRI /National Ethical Review Committee (SSC 1393) and were delinked from the participants and de-identified.

\section{Blood collection and DNA extraction}

Blood was collected through venipuncture, put in sterile $10 \mathrm{ml}$ glass tube this was corked and left overnight at room temperature for serum to separate. Using a sterile pipette serum was discarded and the Peripheral Blood Mononuclear Cells (PBMC) collected for DNA extraction.
DNA was extracted from Peripheral Blood Mononuclear Cells (PBMC) as described by [20]. Then $500 \mu \mathrm{l}$ of DNAzol genomic DNA extraction reagent (Gibco BRL) was added and the pellet dissolved completely by pipetting the reagent - pellet mixture up and down with a pipette. Two volumes $(1000 \mu \mathrm{l})$ of chilled (cooled to $4^{\circ} \mathrm{C}$ ) absolute ethanol were added to the dissolved pellet and mixed gently. This was spun at $3000 \mathrm{~g}$ in a centrifuge for $10 \mathrm{~min}$. The supernatant was discarded and $1000 \mu \mathrm{l}$ of the $70 \%$ ethanol added to the pellet and vortexed thoroughly. This was spun again at $3000 \mathrm{~g}$ in a centrifuge at $4^{\circ} \mathrm{C}$ for $10 \mathrm{~min}$ and the supernatant discarded. The pellet was dried in a safety cabinet at room temperature. DNA pellet was dissolved in $100 \mu$ distilled DNAse and RNAse free water, and stored at $-30^{\circ} \mathrm{C}$ till further use.

\section{Reagents for PCR-RFLP analysis}

For all PCR studies, primers custom-synthesized, dNTP mix and Taq DNA polymerase were used. Restriction enzyme, $B s m B I$ was used as an isoschizomer of Esp 3I and AC1I was used as an isoschizomer of Psp 1406I for RFLP analysis.

\section{CX3CR1 gene polymorphisms}

The starting template was the DNA that had been extracted from PBMCs. The following conditions were adhered to; all the reagents were thawed at room temperature and put in an ice bucket and depending on the number of samples for the PCR reaction, a master mix was made containing the following final concentrations: $2 \mathrm{mM} \mathrm{MgCl} 2$ $\mathrm{mM}$ dNTPs, 0.5 units Taq polymerase, $1 \mathrm{x}$ buffer, $2 \mathrm{ng}$ of each primer and DNA Template giving a total concentration of $25 \mu$. The CX3CR1 primers used were: Forward: 5'-CCGAGGTCCTTCAGGAAATCT-3' and Reverse: 5'TCAGCATCAGGTTCAGGAACTC-3'. The PCR conditions were as follows; $5 \mathrm{~min}$ denaturation at $94^{\circ} \mathrm{C}$ followed by 35 cycles of 1 min denaturation at $94^{\circ} \mathrm{C}, 1 \mathrm{~min}$ annealing at $59^{\circ} \mathrm{C}$ and 1 min extension at $72^{\circ} \mathrm{C}[21]$. Once the PCR was carried out, all products were analyzed by conventional agarose gel electrophoresis whereby, the PCR products were loaded for visualization of the amplified DNA as described by [20]. For the separation of the amplified PCR products we used a $2 \%$ agarose gel containing $0.5 \mu \mathrm{g}$ of Ethidium Bromide $(E t h B r) / \mathrm{ml}$ of gel solution from stock solution $(10 \mathrm{mg} / \mathrm{ml})$. Thus, we added $5 \mu \mathrm{l}$ of stock solution for every $100 \mathrm{ml}$ of gel solution. First a running buffer was made by adding $25 \mu \mathrm{l}(10 \mathrm{mg} / \mathrm{ml})$ of EthBr into 500 $\mathrm{ml}$ of $1 \mathrm{x}$ TBE (Tris-Borate-EDTA) solution. Then to make $500 \mathrm{ml}$ of $2 \%$ agarose gel we added $10 \mathrm{~g}$ of agarose powder to $500 \mathrm{ml}$ of $1 \mathrm{x}$ TBE and the solution was dissolved by warming it up in a microwave for 5-10 $\mathrm{min}$. When the agarose was completely dissolved it was allowed to cool down to $40-50^{\circ} \mathrm{C}$ and $25 \mu \mathrm{l}$ of $\mathrm{EtBr}$ was added and mixed properly. The gel was poured into the gel tank, combs were inserted and allowed to set, being careful to remove all the bubbles present on the gel surface. When the gel had set the comb was removed and the gel placed into the electrophoresis tank filled with $500 \mathrm{ml}$ of running buffer. The total volume of each PCR product $(10 \mu \mathrm{l})$ was then mixed with $2 \mu \mathrm{l}$ of $6 \mathrm{X}$ DNA loading dye and then loaded into the wells of the gel. Electrophoresis was carried out at a constant voltage of $100 \mathrm{~V} / \mathrm{cm}$ using a Mupid'2 plus submarine electrophoresis system power supply. The location of PCR DNA fragments on the gels was visualized by direct examination of the gel under UV light and size estimated by comparing with known molecular weight size markers (Fermentas) loaded alongside them. The PCR products were then run for $1 \mathrm{~h}$ at $55^{\circ} \mathrm{C}$ with $\mathrm{BsmBI}$ for M280 and for $1 \mathrm{~h}$ at $37^{\circ} \mathrm{C}$ with $A C 1 I$ for $\mathrm{I} 249$ polymorphisms. The gels were then digitally photographed using a UV transilluminator (BioSpectrumTM 500 Imaging System, Upland, CA, USA) with VisionWorks LS Image Acquisition and Analysis Software (Version 6.8). 


\section{Statistical analysis}

Data was analyzed using statistical package SPSS version 11.5 to calculate descriptive statistics. With $\mathrm{P}<0.05$ being regarded as significant, differences in genotypic frequencies for the CX3CR1 polymorphisms were examined for significance using the Pearson $\chi^{2}$ test.

\section{Results}

\section{Molecular characterization of the CX3CR1 gene polymorphisms}

Restricted products of CX3CR1 gene from infant and adult samples were digested using Ac1I restriction enzyme and run on a $2 \%$ agarose gel. Five infant samples were run on a four were positive for CX3CR1 gene and showed wild type genes by the appearance of two bands at position 205bp and $383 \mathrm{bp}$ and only sample five was negative with no bands (Figure 1A). Among the five adult samples run on this gel, all were positive for the CX3CR1 gene and showed wild type genes by the appearance of two bands at position $205 \mathrm{bp}$ and $383 \mathrm{bp}$ (Figure 1B). This showed the existence of wild type genes for V249 among infants and adults in the Nairobi population. The samples were then restricted using restriction enzyme BsmBI. Among the five infant samples run on a $2 \%$ agarose gel, four were positive for CX3CR1 gene and showed heterozygous mutant genes by the appearance of four bands at positions $75,216,297$ and $372 \mathrm{bp}$ and only sample four had three bands at positions 75,216 297 bp depicting wild-type genes (Figure 1C). Among the five adult samples run on this gel, all were positive for the CX3CR1 gene showing four bands at positions 75,216,297 and $372 \mathrm{bp}$ depicting heterozygous mutant genes (Figure 1D). This showed the existence of mutations for T280M among infants and adults in the Nairobi population.

\section{Genotype frequencies}

Genotype frequencies among infants for the CX3CR1-V249I showed $45 \%$ wild type genes, $4 \%$ heterozygous mutants and $1 \%$ homozygous mutants among infants. For the CX3CR1-T280M, the genotype frequencies showed $42 \%$ wild type genes, $7 \%$ heterozygous mutants and $1 \%$ homozygous mutants for infants. This showed that infants had higher percentages of wild type genes compared to mutant genes in the Nairobi population (Table 1). Genotype frequencies among adults for the CX3CR1-V249I showed 36\% wild type genes, $12 \%$ heterozygous mutants and $2 \%$ homozygous mutants among adults. For the CX3CR1-T280M, the genotype frequencies showed $37 \%$ wild type genes, $11 \%$ heterozygous mutants and $2 \%$ homozygous mutants among adults. This showed that adults had higher percentages of mutant genes compared wild type genes in the Nairobi population (Table 2). Combined frequencies of both genotypes and haplotypes of the CX3CR1 gene showed that genotypes VV-TT (35\%) and haplotypes VT (57\%) had higher occurrences among infants compared to adults VV-TT (29\%) and haplotypes VT (53\%). The occurrence of genotypes VI-TT (19\%) and VI-TM (4\%) compared to haplotypes IT (28\%) and

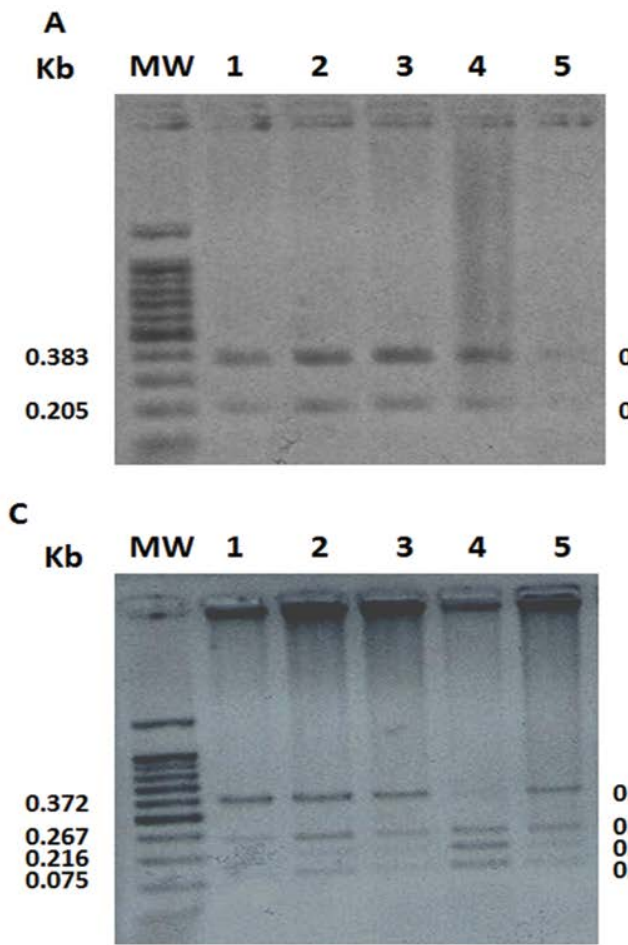

$\begin{array}{lllllll}\text { Kb } & \text { MW } & 1 & 2 & 3 & 4 & 5\end{array}$

0.383

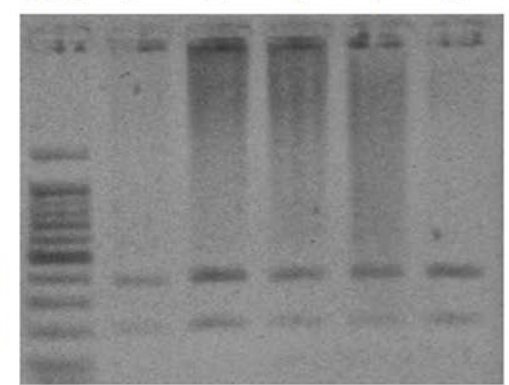

D

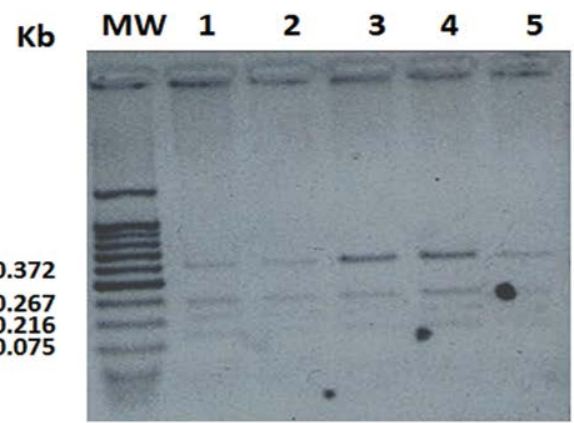

Figure 1: Restricted products of CX3CR1 gene from infant and adult samples. (A) Using restriction enzyme Ac11, five infant samples run on a $2 \%$ agarose gel showed four were positive for the CX3CR 1 gene and were wild type genes by the appearance of two bands at position 205 bp and 383 bp and only sample five was negative with no bands. (B) Among the five adult samples run on a $2 \%$ agarose gel, all were positive for the CX3CR 1 gene and showed wild type genes by the appearance of two bands at position 205 bp and $383 \mathrm{bp}$. Restricted products of CX3CR1 gene from five infant and five adult samples were restricted using restriction enzyme BsmBI. Among the five infant samples run on this gel, four were positive for CX3CR1 gene and showed heterozygous mutant genes by the appearance of four bands at positions $75,216,297$ and 372 bp and only sample four had three bands at positions 75,216 297 bp depicting wildtype genes (C). Among the five adult samples run on this gel, all were positive for the CX3CR1 gene showing four bands at positions $75,216,297$ and 372 bp depicting heterozygous mutant genes (D). 


\begin{tabular}{|c|c|}
\hline Codon 249 & INFANTS $\mathbf{n = 2 0 0}$ \\
\hline $\mathrm{VV}$ & $90(45 \%)$ \\
\hline $\mathrm{VI}$ & $8(4 \%)$ \\
\hline $\mathrm{II}$ & $2(1 \%)$ \\
\hline Codon $\mathbf{2 8 0}$ & \\
\hline $\mathrm{TT}$ & $84(42 \%)$ \\
\hline $\mathrm{TM}$ & $14(7 \%)$ \\
\hline $\mathrm{MM}$ & $2(1 \%)$ \\
\hline
\end{tabular}

Table 1: Genotype frequencies at codons 249 and 280 among infants. Values are number of polymorphisms (\%).

\begin{tabular}{|c|c|}
\hline Codon 249 & ADULTS $\mathbf{n = 2 0 0}$ \\
\hline VV & $72(36 \%)$ \\
\hline VI & $24(12 \%)$ \\
\hline II & $4(2 \%)$ \\
\hline Codon 280 & \\
\hline TT & $74(37 \%)$ \\
\hline TM & $22(11 \%)$ \\
\hline MM & $4(2 \%)$ \\
\hline
\end{tabular}

Table 2: Genotype frequencies at codons 249 and 280 among adults. Values are number of polymorphisms (\%).

IM (5\%) among infants had lower occurrence compared to adult's genotypes VI-TT (20\%) and VI-TM (9\%) compared to haplotypes IT (28\%) and IM (9\%) but in this instance haplotypes IT has the same occurrence of $28 \%$ for both infants and adults (Figure 2).

Analysis of the generated data by Pearson Chi-square distribution showed that the difference between the distribution of the four haplotypes and seven genotypes was not significant, with the T280M mutation at $2 \mathrm{df}$ where the calculated value of 3.077 was lower than the tabulated value of 5.991. This was also not significant with the V249I mutation at $2 \mathrm{df}$ where the calculated value was 5.187 lower than the tabulated value of 5.991 respectively. Thus, there was no significant difference in the frequencies of each of the genotypes and haplotypes $(\mathrm{P}>0.05)$.

\section{Discussion}

\section{Mutations of CX3CR1 co-receptor gene in HIV infected infants}

The results of this study showed that wild type genes of the CX3CR1 gene V249V and T280T alleles were the most common in the infant population with an occurrence of $45 \%$ and $42 \%$, respectively [22]. This suggested that the level of wild type genes was higher compared to that of mutant genes which were $4 \%$ and $7 \%$, respectively for heterozygous mutants and $1 \%$ for homozygous mutants. These results are in agreement with Faure et al. [17], who showed that the wild type genes were the most common alleles in all racial groups being similar in frequency between Caucasian random blood donors from North America (72.2\%) and those from France (74.3\%). This study suggests that this may be due to the fact that the infant's biological systems are still in the early developmental stage where there are minimum or no mutations evidenced in this gene. This concurred to a previous study that hypothesized that this may be due to the infant's biological systems being less well developed as they still relied on maternal antibodies and also that CD4 T-cell are easily replaced at a younger age, perhaps because of the capacity of the thymus to generate new naive CD4 T-cells [23]. This was the first study carried out in Kenya on CX3CR1 gene polymorphisms. The results of this study showed the presence of high percentages of wild type alleles compared to the mutant alleles. Singh et al. [18], hypothesized that children with the wild-type CX3CR1 V/ V249 genotype which had been associated with greater binding to fractalkine, compared with that in individuals with the I/I249 genotype experienced slower HIV-1 disease progression than children with the I/I249 genotype, similarly the T280 allelic variant, also associated with enhanced binding of fractalkine, was associated with slower disease progression, compared with the M280 allele. This however cannot be conclusively said for this study unless a cohort study is carried out in Kenya to ascertain the slower disease progression among infants. Stiehm et al. [24], demonstrated two general patterns of illness existed in HIV-infected children, with about $20 \%$ developing serious disease in the first year of life, while the remaining $80 \%$ showed slower rate of disease progression with many not developing the symptoms of AIDS until school entry or even adolescence. This could also be the case in the Kenyan population as evidenced by this study where there were higher percentages of the wild type genes among infants for the two genes V249V and T280T. Heterozygous mutants of the CX3CR1 gene were also observed in this study. The V249I and T280M mutant alleles which had lower percentages $4 \%$ and $7 \%$, respectively compared to the wild type alleles $45 \%$ and $42 \%$ respectively for infants. Homozygous mutants I249I and M280M were also observed in this study and they had the lowest percentages compared to the other alleles both having $1 \%$. Suresh et al. [21], also observed the same lower percentages of heterozygous and homozygous mutants compared to wild type alleles. Since these low levels of mutants had no impact with regards to HIV1 resistance in infants, it is suggested that these polymorphisms exert their effects during later stages of HIV-1 infection [18].This could have been one of the reasons why this study showed higher percentages of wild type alleles (42\%-45\%) compared to mutant alleles (1\%-7\%) in the Kenyan population.

\section{Mutations of CX3CR1 co-receptor gene in HIV infected adults}

Wild type genes of the CX3CR1 gene V249V and T280T were the most common alleles observed the adult population a percentage of $36 \%$ and $37 \%$, respectively. This depicts a higher level of wild type alleles compared to the mutant alleles in this population. Compared to infants, the frequency of wild type genes tend to decrease with increase

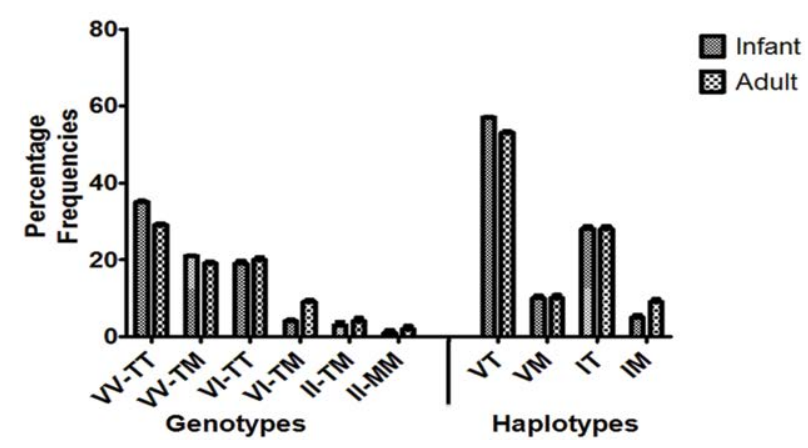

Figure 2: Combined frequencies of genotypes and haplotypes among infants and adults. Combined frequencies of both genotypes and haplotypes of the CX3CR1 gene showed that genotypes VV-TT (35\%) and haplotypes VT $(57 \%)$ had higher occurrences among infants compared to adults VTTT $(29 \%)$ and haplotypes VT $(53 \%)$. The occurrence of genotypes VI-TT (19\%) and VI-TM (4\%) compared to haplotypes IT (28\%) and IM (5\%) among infants had lower occurrence compared to adult's genotypes VI-TT $(20 \%)$ and VI-TM $(9 \%)$ compared to haplotypes IT $(28 \%)$ and IM $(9 \%)$ but in this instance haplotypes IT has the same occurrence of $28 \%$ for both infants and adults. 
in age. This was also observed by other studies that showed a decrease in wild type alleles in adults compared to infants, with the relative risk of disease progression increasing 1.5 -fold for every ten years $[16,25]$. We hypothesized this to be as a result of environmental and genetic changes that occur with age. Heterozygous mutants of the CX3CR1 gene were observed in this study. V249I and T280M mutations had lower percentages (12\% and $11 \%)$, respectively, compared to the wild type alleles for adults ( $36 \%$ and $37 \%$ ), respectively. In this study these percentages were much higher than among those of infants $(4 \%$ and $11 \%)$, respectively. Homozygous mutants I249I and M280M were also observed in this study and had the lowest percentages compared to the other alleles both having $2 \%$. These percentages were also higher than those of infants (1\%). This showed an increase in mutations with increase in age in the population. This being in agreement with Morgan et al. [23], he showed that older people may have lower levels of chemokines, making it harder for HIV to infect CD4 T-cells. These mutant alleles were also found at higher frequency in a cohort of Caucasian HIVinfected patients progressing to AIDS faster than normal [17]. This trend was observed in another study evaluating individuals entering HAART treatment during one year, the I249 polymorphism was found at a higher frequency among those displaying early immunological failure, estimated as a decline in CD4 counts [16]. The results of this study showed low percentages of mutant alleles in the adult Kenyan population. Though, larger cohort studies need to be carried out in the Kenyan setting to conclusively ascertain the levels of these mutations and the role they might play in leading to a faster progression to AIDS than normal.

\section{Differences in mutations of CX3CR1 co-receptor gene occurring among HIV infected adults and infants}

Differences in CX3CR1 gene mutations were observed among both infants and adults with the infants having higher percentages of the wild type alleles and lower percentages of mutant alleles compared to adults. Since the impact of specific polymorphisms in CX3CR1 on HIV1 associated disease could vary with the diverse genetic backgrounds present in different racial/ethnic groups [18], this study examined the distribution of genotypes within Nairobi. It was observed that the wild type genes VV-TT had higher percentages (35\% and 29\%), respectively compared to the other combination of mutations showing that the infant population in Nairobi had a higher number of wild type genes compared to mutant genes. From this study the CX3CR1 haplotypes distribution in infant showed a higher percentage with haplotypes VT than with haplotypes IM showing that the studied population was not influenced by the homozygous gene. In a previous study on a Spanish cohort it was found that the haplotype IT was overrepresented among long-term nonprogressors (LTNPs,) as compared to normal progressors VT [17]. This being in agreement with this study, which showed higher percentages of haplotypes VT and lower percentages of haplotypes IM but the hypothesized conclusion of LTNPs in the previous study can not be conclusively shown by this study. This study showed that the mutations observed were not statistically significant $(P>0.05)$ suggesting that these mutations had no effect on HIV pathogenesis in the Nairobi population. The results of this study showed, heterozygous mutant V/I249 combined with individuals with wild type T/T280 and also heterozygous mutant V/I249 combined with individuals with heterozygous mutant T/M280 adults had higher percentages $(20 \%$ and $9 \%$ ) respectively compared to infants (19\% and $4 \%$ ), respectively. This showed infants had higher levels of wild type genes compared to mutant genes in the Nairobi population. The differences in mutations of CX3CR1 allele in I249 and M280 in this study was $p=0.075$ and $\mathrm{p}=0.215$, respectively which was not statistically significant $(\mathrm{p}>0.05)$.
These results compare well with observations in a previous study on Caucasians where the prevalence of CX3CR1 allele was observed to be higher in I249 (26\%) than M280 (14\%) though statistically insignificant [19]. This study observed that the CX3CR1 wild type V249 and T280 genotypes with the haplotypes VT had the highest percentages in the population and that the CX3CR1 homozygous genotypes 249I and $280 \mathrm{M}$ with the haplotypes IM had the lowest percentages. This showed that HIV-1 progression in this population was not dependent on CX3CR1 gene polymorphisms suggesting that CX3CR1 mutations had no effect on HIV pathogenesis in the Nairobi population.

\section{Limitations}

This is a retrospective study that only includes a limited number of samples from infants and adults. Thus the data is not fully representative of the Kenyan population but the results be used to form a baseline study for future cohort studies to be done in Kenya.

\section{Conclusion}

We conclude that CX3CR1 gene polymorphisms exist in Nairobi Province with infants having the highest percentages of wild type alleles compared to adults who had higher percentages of mutant alleles. The level of the wild type alleles decreased with increase in age and mutant alleles increased with increase in age. There is a considerable difference between infant and adult mutations with adults having a higher percentage of mutant alleles. Despite the higher percentages of mutant alleles in adults compared to infants these were still at very low levels to warrant any meaningful impact in the population in terms of HIV-1 disease progression and maybe alternative mechanisms might be operating in conferring resistance to HIV-1 infection.

\section{Authors' Contributions}

Conceived and designed the experiments: LMM, SAK, ZWN. Performed the experiments: LMM, BBM, SPM. Analyzed the data: LMM, SAK. Contributed reagents/materials/analysis tools: LMM, SAK. Wrote the paper: LMM, SAK, ZAN. All authors read and approved the final manuscript.

\section{Acknowledgement}

The authors wish to thank the Kenya Medical Research Institute-Centre for Virus Research (KEMRI-CVR) and the Institute of Tropical Medicine and infectious Diseases, Jomo Kenyatta University of Agriculture and Technology (ITROMID-JKUAT) for supporting the study.

\section{Funding}

This work was supported by Kenya Medical Research Institute-Centre for Virus Research (KEMRI-CVR). The funders had no role in study design, data collection and analysis, decision to publish,or preparation of the manuscript.

\section{References}

1. Vidal F, Viladés $C$, Domingo $P$, Broch $M$, Pedrol $E$, et al (2005) Spanish HIV 1 -infected long-term non-progressors of more than 15 years have an increased frequency of the CX3CR1 249I variant allele. J Acquir Immune Defic Syndr 40 527-531.

2. Deng H, Liu R, Ellmeier W, Choe S, Unutmaz D, et al. (1996) Identification of a major co-receptor for primary isolates of HIV-1. Nature 381: 661-666.

3. Singh KK, Barroga CF, Hughes MD, Chen J, Raskino C, et al. (2003) Genetic influence of CCR5, CCR2 and SDF1 variants on human immunodeficiency virus 1 (HIV-1)-related disease progression and neurological impairment, in children with symptomatic HIV-1 infection. J Infect Dis 188: 1461-1472.

4. Ma L, Marmor M, Zhong P, Ewane L, Su B, et al. (2005) Distribution of CCR264 I and SDF1-3'A alleles and HIV status in 7 ethnic populations of Cameroon. J Acquir Immune Defic Syndr 40: 89-95. 
Citation: Mwapagha LM, Ng'ang'a ZW, Mutuiri SP, Miheso BB, Khamadi SA (2017) Genetic Polymorphisms of the CX3CR1 Gene Associated with HIV-1 Infections in Kenyan Population. J AIDS Clin Res 8: 712. doi: 10.4172/2155-6113.1000712

Page 6 of 6

5. Rathore A, Chatterjee A, Sivarama P, Yamamoto N, Singhal PK, et al. (2008) Association of RANTES $-403 \mathrm{G} / \mathrm{A},-28 \mathrm{C} / \mathrm{G}$ and $\ln 1.1 \mathrm{~T} / \mathrm{C}$ polymorphism with HIV-1 transmission and progression among North Indians. J Med Virol 80: $1133-1141$.

6. Mhandire K, Duri K, Kandawasvika G, Chandiwana P, Chin'ombe N, et al. (2014) CCR2, CX3CR1, RANTES and SDF1 genetic polymorphisms influence HIV infection in a Zimbabwean pediatric population. J Infect Dev Ctries 8: 1313 1321.

7. Mutuiri SP, Kutima HL, Mwapagha LM, Munyao JK, Nyamache AK, et al. (2016) RANTES Gene Polymorphisms Associated with HIV-1 Infections in Kenyan Population. Dis Markers 2016: 4703854

8. Madec Y, Boufassa F, Rouzioux C, Delfraissy JF, Meyer L; SEROCO Study Group (2005) Undetectable viremia without antiretroviral therapy in patients with HIV seroconversion: An uncommon phenomenon? Clin Infect Dis 40: 1350-1354.

9. Moyle GJ, Wildfire A, Mandalia S, Mayer H, Goodrich J, et al. (2005) Epidemiology and predictive factors for chemokine receptor use in HIV-1 infection. J Infect Dis 191: 866-872.

10. Broström C, Visco-Comandini U, Yun Z, Sönnerborg A (1999) Longitudinal quantification of human immunodeficiency virus type 1 DNA and RNA in longterm non-progressors. J Infect Dis 179: 1542-1548.

11. Kondo M, Shima T, Nishizawa M, Sudo K, Iwamuro S, et al. (2005) Identification of attenuated variants of HIV-1 circulating recombinant form 01_AE that are associated with slow disease progression due to gross genetic alterations in the nef/long terminal repeat sequences. J Infect Dis 192: 56-61.

12. Tong N, Perry SW, Zhang Q, James HJ, Guo H, et al. (2000) Neuronal fractalkine expression in HIV-1 encephalitis: Roles for macrophage recruitment and neuroprotection in the central nervous system. J Immunol 164: 1333-1339.

13. Bucy RP, Hockett RD, Derdeyn CA, Saag MS, Squires K, et al. (1999) Initial increase in blood CD4(+) lymphocytes after HIV antiretroviral therapy reflects redistribution from lymphoid tissues. J Clin Invest 103: 1391-1398.

14. Laprise C, Sladek R, Ponton A, Bernier MC, Hudson TJ, et al. (2004) Functional classes of bronchial mucosa genes that are differentially expressed in asthma. BMC Genomics 5: 21.

15. Sukkar MB, Issa R, Xie S, Oltmanns U, Newton R, et al. (2004) Fractalkine/
CX3CL1 production by human airway smooth muscle cells: induction by IFN-? and TNF-a and regulation by TGF- $ß$ and corticosteroids. Am J Physiol Lung Cell Mol Physiol 287: L1230-L1240.

16. McDermott DH, Colla JS, Kleeberger CA, Plankey M, Rosenberg PS, et al. (2000) Genetic polymorphism in CX3CR1 and risk of HIV disease. Science 290: 2031

17. Faure S, Meyer L, Costagliola D, Vaneensberghe C, Genin E, et al. (2000) Rapid progression to AIDS in HIV+ individuals with a structural variant of the chemokine receptor CX3CR1. Science 287: 2274-2277.

18. Singh KK, Hughes MD, Chen J, Spector SA (2005) Genetic polymorphisms in CX3CR1 predict HIV-1 disease progression in children independently of CD4+ lymphocyte count and HIV-1 RNA load. J Infect Dis 191: 1971-1980.

19. Lama J, Planelles $V$ (2007) Host factors influencing susceptibility to HIV infection and AIDS progression. Retrovirology 4: 52.

20. Khamadi SA, Ochieng W, Lihana RW, Kinyua J, Muriuki J, et al. (2005) HIV type 1 subtypes in circulation in northern Kenya. AIDS Res Hum Retroviruses 21: $810-814$

21. Suresh $P$, Wanchu A, Sachdeva RK, Bhatnagar A (2006) Gene polymorphisms in CCR5, CCR2, CX3CR1, SDF-1 and RANTES in exposed but uninfected partners of HIV-1 infected individuals in North India. J Clin Immunol 26: 476-484.

22. Mwapagha LM (2012) Characterization of Polymorphisms of the CX3CR1 Co-receptor gene among HIV infected adults and infants in Nairobi province, Kenya. JKUAT Abstracts of postgraduate thesis.

23. Morgan D, Mahe C, Mayanja B, Okongo JM, Lubega R, et al. (2002) HIV-1 infection in rural Africa: is there a difference in median time to AIDS and survival compared with that in industrialized countries? AIDS 16: 597-603.

24. Stiehm ER, Lambert JS, Mofenson LM, Bethel J, Whitehouse J, et al. (1999) Efficacy of zidovudine and human immunodeficiency virus (HIV) hyperimmune immunoglobulin for reducing perinatal HIV transmission from HIV-infected women with advanced disease: Results of Pediatric AIDS Clinical Trials Group protocol 185. J Infect Dis 179: 567-575.

25. Pezzotti P, Phillips AN, Dorrucci M, Lepri AC, Galai N, et al. (1996) Category of exposure to HIV and age in the progression to AIDS: Longitudinal study of 1199 people with known dates of seroconversion. HIV Italian Seroconversion Study Group. BMJ 313: 583-586. 